\title{
A Study on the Connection Effects of Subsurface Slabs to Exterior Walls in the KNGR Seismic Analysis
}

\author{
Young-Sun Jang, Yong-Sun Lee and Tae-Young Kim
}

Korea Power Engineering Company, Inc., Korea

ASTRACT : The SSI(Soil-Structure Interaction) analyses are being performed for the KNGR(Korean Next Generation Reactor) design, because the KNGR is developed as a standard nuclear power plant concept enveloping various soil conditions. The SASSI program which adopts the flexible volume method is used for the SSI analyses. Because the impedances are computed based on the assumption of a rigid foundation in the KNGR design, the impedances are computed at a single point around the center of the basemat. The base model used in the SSI analyses assumed that the subsurface slabs are free and not connected to the exterior walls. This results in a more flexible structure than reality. This study is performed to address the concern of the potential dynamic effect of this modeling assumption on the overall structural response. The super-structure model is modified with the subsurface portions of the sticks being laterally rigid, so that the entire subsurface cavity together with the super-structure model acts laterally rigid. For the comparison, the in-structure response spectra using the rigid subsurface model are compared with the original spectra without considering the connection effects.

\section{INTRODUCTION}

The KNGR is developed as a standard nuclear power plant concept. Therefore this KNGR design has been developed for a wide range of site conditions from rock to soil. The standard design refers to a design which would be suitable for construction on any given site without performing the site specific analysis and design. In order to design the plant for an envelope of site conditions, a series of SSI analyses are performed. The seismic analyses have been executed using not only a rock case but also eight soil sites which represent the postulated generic site characteristics.

All the structures are modeled by the lumped-mass stick models for each individual structure using beam elements. In the super-structure model, the slabs below ground surface are free and not connected to the exterior walls. This is generally considered conservative since the exterior wall, as a part of the super-structure model, may deform more without considering the local restraint of the side soil.

This study is performed to address the concern of the potential dynamic effect on the in-structure responses due to the local connection of the subsurface slabs with the exterior walls and the soil. The connection of the subsurface slabs to exterior walls is achieved by assigning rigid properties to the four vertical sticks representing the subsurface story walls in the horizontal model of the Nuclear Island.

Among the generic 8 soil cases, one soil case(B4) is chosen for this study.

In this SSI analysis, two different sets of input ground motions are used, each set 
consisting of two horizontal motions and one vertical motion applied simultaneously. The two sets of input motions are designated as CMS1(based on Reg Guide 1.60 design spectrum which is applied as a surface motion) and CMS3(based on NUREG/CR-0098 which is for application at the rock outcrop) as shown in Fig. 1.

To perform the SSI analysis, the computer program SASSI(Reference 2) is used. The program SASSI(System for Analysis of Soil-Structure Interaction) uses finite element techniques and a complex response method in the frequency domain to solve dynamic soil-structure interaction problems in two or three dimensions.

\section{KNGR SEISMIC ANALYSIS AND DESIGN}

\subsection{Site Conditions}

The potential sites for construction of the KNGR standard design will consist of rock sites and soil sites with soil layers having a total depth of up to about $200 \mathrm{ft}$. Generic soil sites were selected by first choosing three generic site categories. These categories were chosen to represent appropriate total thickness of soil overlying bedrock. Site Category A consists of approximately 53 feet of soil overlying bedrock; 53 feet is the approximate embedment depth of the Nuclear Island. The soils in Category B extend to a depth of 100 feet and those in Category $\mathrm{C}$ extend to a depth of 200 feet. The three categories are shown schematically in Fig. 2.

The minimum low-strain shear wave velocity is $1000 \mathrm{ft} / \mathrm{sec}$ at the surface and 1300 $\mathrm{ft} / \mathrm{sec}$ at the bedrock interface. Parabolic variations of the low-strain shear wave velocities with depth were assigned for each soil case, as summarized in Table 1.

The variation of shear modulus with shear strain, is chosen as the upper curve from the range published by Seed and Idriss(Reference 3). The variation of damping with shear strain, is chosen as the lower curve from the range published in Reference 3.

\subsection{Super-Structure Modeling}

The general arrangement of the KNGR Nuclear Island is shown in Fig. 3. The Nuclear Island(NI) contains :

- Auxiliary Building including Outer Containment

- Inner Containment

- Containment Internals including Reactor Coolant System

The NI structures are founded on a $10 \mathrm{ft}$ thick concrete basemat(top EL. $55^{\prime}-0^{\prime \prime}$ ) with dimensions of $367 \mathrm{ft} \times 296 \mathrm{ft}$, and embedded $53 \mathrm{ft}-8 \mathrm{in}$ into the soil. Ground elevation is at Elevation $98^{\prime}-8^{\prime \prime}$.

As shown in Fig. 4, three-dimensional lumped-mass stick models of each individual structures were developed using beam elements. The 4 different area stick models of the Auxiliary Building which are connected with the Outer Containment stick were developed, and tuned with 3-D FEM model in dynamic properties.

The stick models are then combined with the Inner Containment and Containment Internals including RCS to form a composite model of the Nuclear Island. The lumped-mass stick model for each area is developed by defining major floor elevations and those elevations at which significant stiffness discontinuities occur across the entire area of the structure. 


\subsection{SSI Analysis Methodology for KNGR}

\section{1) SASSI Program}

The general SASSI program uses a sub-structuring method, which is formulated in the frequency domain using the complex response method and the finite element technique. The finite element discretization, in order to capture the embedded soil profile and the frequency range of interest, would require such a large number of interaction nodes that will be impractical to compute the behavior of the KNGR Nuclear Island structures by the general SASSI methodology.

\section{2) Computation of Impedances}

By taking advantage of the foundation rigidity, a modified method of the SASSI module RIMP was used, which greatly reduces the computational effort required. Frequency dependent impedances, at specified frequencies, are computed by the module RIMP. RIMP has the capability to compute impedance matrices of a single rigid embedded foundation of arbitrary shape.

In this analysis, the foundation is assumed to be rigid. Therefore, the complete flexibility matrix of all interaction nodes can be transformed into the flexibility matrix of a single point, by rigid body transformation. The transformation is performed based on the geometry of the foundation. The foundation stiffness is not required because of the inherent rigid body assumption.

To compute the impedance matrix, the inversion of the flexibility matrix (size $6 \times 6$ ) of a single point(say, the center of the foundation) is required.

\section{3) Computation of Scattering}

While RIMP computes the impedance matrix, it does not compute the scattering matrices required to compute the foundation response due to input motions at the ground surface. RIMP assumes a scattering matrix with constant values of 1.0 for all input directions. This implies that the motion at the surface and at the foundation level are identical. For significant embedment, such as that for the KNGR structures, having embedments depth of $53 \mathrm{ft}$, the assumption is not realistic. Due to the response of the embedded soil, the motion at the foundation level may be considerably less than that at the surface. Using the general SASSI approach, the scattering matrices related to the foundation response due to a control motion applied at the soil surface are computed by using the two 2-D models of the foundation. The results from the two-dimensional models are combined later to derive a $6 \times 3$ scattering matrix for the 3-D foundation, which is frequency-dependent, at the point where the super-structure is attached to the foundation, for each discrete frequency of interest.

\section{4) Generation of Transfer Functions}

Transfer functions at key locations of the structure are generated after computations of the impedance and scattering matrix. Since the SSI analyses are performed in the frequency domain, transfer functions are calculated up to a maximum specified frequency. This frequency is commonly referred to as the "cutoff" frequency, which depends on the mesh size, the soil layer thickness and the soil layer properties. 


\section{5) Generation of Responses}

Generation of response involves the computation of acceleration time histories at selected in-structure locations, combinations of these time histories at specified frequency points and damping values.

\subsection{Development of In-structure Broadened Spectra}

In-structure spectra were developed for all SSI cases. These spectra and the one corresponding to the rock condition were combined and broadened to form the basis for the KNGR standard design in-structure response spectra.

\subsection{Extraction of Seismic Response Parameters}

All shear force, moment, axial force and acceleration profiles were extracted for all the 8 soil cases. The resulting data were tabulated and plotted demonstrating the resulting response parameter for each design case as well as the enveloped condition, also incorporating the rock site condition.

\section{PARAMETRIC ANALYSIS}

\subsection{Analysis Case}

Since the purpose of this study is to determine the effect of connecting the subsurface slabs to exterior walls in B4 case, it is sufficient to examine the structural responses at a few representative locations where the responses are expected to be sensitive to this effect. For reference, this parametric study case will be named as B4S. Such representative responses include:

- Total member forces(axial and shear) at the base of the Auxiliary Building, and member forces at the base of the Inner Containment and the base of the Primary and Secondary Shield.

- The 5\% damped FRS at four locations: roof of the Auxiliary Building(Node 181) and top of the Outer Containment Dome(Node 641), top of the Inner Containment Dome(Node 715), and top of the Primary-Secondary Shield(Node 737).

\subsection{Rigid Beam Properties for Exterior Wall Effects}

The effect of connecting the subsurface slabs to exterior walls is achieved by assigning rigid properties to the four vertical sticks representing the subsurface story walls in the horizontal model of the Auxiliary Building. Since the effect being simulated is only in the horizontal direction, vertical model is not changed.

\section{RESULTS}

The responses that are available for comparison from this study are the base shear forces and the response spectra.

Table 2 shows the comparison of the base shear forces in the three representative structures for both control motions.

In the Auxiliary Building, the base shear forces of B4 case are larger than B4S 
results for both control motions and each directions, respectively. In the Inner Containment, the EW directional base shear force of B4S using CMS3 input motion is $8 \%$ larger than that of B4 case. In the Primary and Secondary Shield Wall, the NS directional base shear force of $\mathrm{B} 4 \mathrm{~S}$ using CMS3 input motion is $1 \%$ larger than that of $\mathrm{B} 4$ case.

Fig. 5 to 8 show the comparisons of the three components of the $5 \%$ damping FRS at the four representative structural locations. There are a minimal frequency shift in in-structure response spectra. The floor response spectra for the Auxiliary Building in the EW direction are concordant with each other. At all locations of other NI structure, the response spectra of $\mathrm{B} 4$ case are similar to $\mathrm{B} 4 \mathrm{~S}$ in low frequency range - about $2.5 \mathrm{~Hz}$, but the results of $\mathrm{B} 4$ are larger than those of $\mathrm{B} 4 \mathrm{~S}$ cases in high frequency range - about $8 \sim 12 \mathrm{~Hz}$.

\section{CONCLUSIONS}

Through this parametric study, the potential dynamic effects on the in-structure responses due to the local connection of the subsurface slabs with the exterior walls and the soil were checked for the KNGR Nuclear Island stick model. The results can be summarized as follows :

- The base member forces in representative three NI structures are enveloped by the corresponding base member forces envelopes.

- There is a minimal frequency shift in in-structure response spectra due to the connection effect.

- The response spectra of the B4S case are slightly higher than those of the B4 case for the low frequency range which may impact on building and/or equipment or piping design.

A more detailed model providing appropriate beam properties may result in more realistic response due to this connection effect.

\section{REFERENCES}

1. 'KNGR Technical Report - Seismic Input Motion', Doc. No. N-200-ECD425-001, KEPRI, 1998, Taejon, KOREA

2. 'SASSI(System for Analysis of Soil-Structure Interaction) User's Manual', DE\&S Version 4.1, Dec. 1997, San Ramon, USA

3. Seed, H.B. and Idriss, I. M., 'Soil Moluli and Damping Factors for Dynamic Response Analyses', Report No. EERC 70-10, University of California, Berkeley, 1970. 
Table 1. Variation of Low Strain Shear Wave Velocity in Soils with Depth Below Surface for Generic Soil

Cases

\begin{tabular}{|c|c|c|c|c|c|c|c|c|}
\hline $\begin{array}{l}\text { Depth } \\
\text { Below } \\
\text { Surface }\end{array}$ & $\begin{array}{c}\text { Soil } \\
\text { Case } \\
\text { A-1 }\end{array}$ & $\begin{array}{c}\text { Soil } \\
\text { Case } \\
\text { B-1 }\end{array}$ & $\begin{array}{l}\text { Soil } \\
\text { Case } \\
\text { B-2 }\end{array}$ & $\begin{array}{c}\text { Soil } \\
\text { Case } \\
\text { B-3 }\end{array}$ & $\begin{array}{l}\text { Soil } \\
\text { Case } \\
\text { B-4 }\end{array}$ & $\begin{array}{l}\text { Soil } \\
\text { Case } \\
\text { C-1 }\end{array}$ & $\begin{array}{l}\text { Soil } \\
\text { Case } \\
\text { C-2 }\end{array}$ & $\begin{array}{l}\text { Soil } \\
\text { Case } \\
\text { C-3 }\end{array}$ \\
\hline $\begin{array}{c}0 \mathrm{ft} \\
\text { to }\end{array}$ & $\begin{array}{c}1800 \\
\text { to }\end{array}$ & $\begin{array}{c}1000 \\
\text { to }\end{array}$ & $\begin{array}{c}1400 \\
\text { to }\end{array}$ & $\begin{array}{c}1800 \\
\text { to }\end{array}$ & $\begin{array}{c}1000 \\
\text { to }\end{array}$ & $\begin{array}{c}1000 \\
\text { to }\end{array}$ & $\begin{array}{c}1800 \\
\text { to }\end{array}$ & $\begin{array}{c}1000 \\
\text { to }\end{array}$ \\
\hline $53 \mathrm{ft}$ & $\begin{array}{l}2200 \\
\mathrm{ft} / \mathrm{sec}\end{array}$ & $\begin{array}{l}1234 \\
\mathrm{ft} / \mathrm{sec}\end{array}$ & $\begin{array}{l}1712 \\
\mathrm{ft} / \mathrm{sec}\end{array}$ & $\begin{array}{l}2267 \\
\mathrm{ft} / \mathrm{sec}\end{array}$ & $\begin{array}{l}1200 \\
\mathrm{ft} / \mathrm{sec}\end{array}$ & $\begin{array}{l}1276 \\
\mathrm{ft} / \mathrm{sec}\end{array}$ & $\begin{array}{l}2260 \\
\mathrm{ft} / \mathrm{sec}\end{array}$ & $\begin{array}{l}1220 \\
\mathrm{ft} / \mathrm{sec}\end{array}$ \\
\hline $\begin{array}{l}53 \mathrm{ft} \\
\text { to } \\
100 \mathrm{ft}\end{array}$ & Rock & $\begin{array}{c}1234 \\
\text { to } \\
1300 \\
\mathrm{ft} / \mathrm{sec} \\
\end{array}$ & $\begin{array}{c}1712 \\
\text { to } \\
1800 \\
\mathrm{ft} / \mathrm{sec} \\
\end{array}$ & $\begin{array}{c}2267 \\
\text { to } \\
2400 \\
\mathrm{ft} / \mathrm{sec} \\
\end{array}$ & $\begin{array}{c}2200 \\
\text { to } \\
2400 \\
\mathrm{ft} / \mathrm{sec} \\
\end{array}$ & $\begin{array}{c}1276 \\
\text { to } \\
1450 \\
\mathrm{ft} / \mathrm{sec}\end{array}$ & $\begin{array}{c}2260 \\
\text { to } \\
2550 \\
\mathrm{ft} / \mathrm{sec}\end{array}$ & $\begin{array}{c}1220 \\
\text { to } \\
1300 \\
\mathrm{ft} / \mathrm{sec}\end{array}$ \\
\hline $\begin{array}{l}100 \mathrm{ft} \\
\text { to } \\
200^{\mathrm{ft}}\end{array}$ & Rock & Rock & Rock & Rock & Rock & $\begin{array}{c}1450 \\
\text { to } \\
1600 \\
\mathrm{ft} / \mathrm{sec} \\
\end{array}$ & $\begin{array}{c}2550 \\
\text { to } \\
2800 \\
\mathrm{ft} / \mathrm{sec} \\
\end{array}$ & $\begin{array}{c}2600 \\
\text { to } \\
2800 \\
\mathrm{ft} / \mathrm{sec} \\
\end{array}$ \\
\hline $\begin{array}{l}200 \mathrm{ft} \\
\text { and } \\
\text { Greater }\end{array}$ & Rock & Rock & Rock & Rock & Rock & Rock & Rock & Rock \\
\hline
\end{tabular}

Note:

(1) Parabolic variation of shear wave velocity with depth is assumed.

(2) Rock is characterized by a shear wave velocity of $5000 \mathrm{ft} / \mathrm{sec}$.

Table 2 Comparison of Base Member Forces

(a) Auxiliary Building

\begin{tabular}{|l|c|c|c|c|c|c|}
\hline & \multicolumn{3}{|c|}{ CMS1 } & \multicolumn{3}{c|}{ CMS3 } \\
\hline & $\begin{array}{c}\text { Vertical } \\
\text { Axial } \\
\text { Force } \\
\text { P1 (kip) }\end{array}$ & $\begin{array}{c}\text { EW- } \\
\text { Direction } \\
\text { Shear } \\
\text { P2 (kip) }\end{array}$ & $\begin{array}{c}\text { NS- } \\
\text { Direction } \\
\text { Shear } \\
\text { P3 (kip) }\end{array}$ & $\begin{array}{c}\text { Vertical } \\
\text { Axial } \\
\text { Force } \\
\text { Pl (kip) }\end{array}$ & $\begin{array}{c}\text { EW- } \\
\text { Direction } \\
\text { Shear } \\
\text { P2 (kip) }\end{array}$ & $\begin{array}{c}\text { NS- } \\
\text { Direction } \\
\text { Shear } \\
\text { P3 (kip) }\end{array}$ \\
\hline $\begin{array}{l}\text { Envelope of All } \\
\text { Soil Cases \& } \\
\text { Control Motions }\end{array}$ & $2.48 \mathrm{E} 5$ & $3.36 \mathrm{E} 5$ & $3.92 \mathrm{E} 5$ & $2.48 \mathrm{E} 5$ & $3.36 \mathrm{E} 5$ & $3.92 \mathrm{E5}$ \\
\hline Case B4 & $2.48 \mathrm{E} 5$ & $2.31 \mathrm{E} 5$ & $2.91 \mathrm{E5}$ & $2.14 \mathrm{E} 5$ & $2.65 \mathrm{E} 5$ & $3.09 \mathrm{E} 5$ \\
\hline Case B4S & $2.46 \mathrm{E} 5$ & $2.18 \mathrm{E} 5$ & $2.65 \mathrm{E} 5$ & $2.03 \mathrm{E} 5$ & $2.53 \mathrm{E} 5$ & $2.72 \mathrm{E} 5$ \\
\hline
\end{tabular}


Table 2 Comparison of Base Member Forces(continued)

(b) Inner Containment

\begin{tabular}{|l|c|c|c|c|c|c|}
\hline & \multicolumn{3}{|c|}{ CMS1 } & \multicolumn{3}{|c|}{ CMS3 } \\
\hline & $\begin{array}{c}\text { Vertical } \\
\text { Axial } \\
\text { Force } \\
\text { P1 (kip) }\end{array}$ & $\begin{array}{c}\text { EW- } \\
\text { Direction } \\
\text { Shear } \\
\text { P2 (kip) }\end{array}$ & $\begin{array}{c}\text { NS- } \\
\text { Direction } \\
\text { Shear } \\
\text { P3 (kip) }\end{array}$ & $\begin{array}{c}\text { Vertical } \\
\text { Axial } \\
\text { Force } \\
\text { P1 (kip) }\end{array}$ & $\begin{array}{c}\text { EW- } \\
\text { Direction } \\
\text { Shear } \\
\text { P2 (kip) }\end{array}$ & $\begin{array}{c}\text { NS- } \\
\text { Direction } \\
\text { Shear } \\
\text { P3 (kip) }\end{array}$ \\
\hline $\begin{array}{l}\text { Envelope of All } \\
\text { Soil Cases \& } \\
\text { Control Motions }\end{array}$ & $4.70 \mathrm{E} 4$ & $6.91 \mathrm{E} 4$ & $6.69 \mathrm{E} 4$ & $4.70 \mathrm{E} 4$ & $6.91 \mathrm{E} 4$ & $6.69 \mathrm{E} 4$ \\
\hline Case B4 & $2.61 \mathrm{E} 4$ & $3.13 \mathrm{E} 4$ & $4.09 \mathrm{E} 4$ & $1.94 \mathrm{E} 4$ & $4.27 \mathrm{E} 4$ & $4.82 \mathrm{E} 4$ \\
\hline Case B4S & $2.61 \mathrm{E} 4$ & $3.04 \mathrm{E} 4$ & $3.99 \mathrm{E} 4$ & $1.94 \mathrm{E} 4$ & $4.61 \mathrm{E} 4$ & $4.64 \mathrm{E} 4$ \\
\hline
\end{tabular}

(c) Primary \& Secondary Shield

\begin{tabular}{|l|c|c|c|c|c|c|}
\hline & \multicolumn{3}{|c|}{ CMS1 } & \multicolumn{3}{c|}{ CMS3 } \\
\hline & $\begin{array}{c}\text { Vertical } \\
\text { Axial } \\
\text { Force } \\
\text { P1 (kip) }\end{array}$ & $\begin{array}{c}\text { EW- } \\
\text { Direction } \\
\text { Shear } \\
\text { P2 (kip) }\end{array}$ & $\begin{array}{c}\text { NS- } \\
\text { Direction } \\
\text { Shear } \\
\text { P3 (kip) }\end{array}$ & $\begin{array}{c}\text { Vertical } \\
\text { Axial } \\
\text { Force } \\
\text { P1 (kip) }\end{array}$ & $\begin{array}{c}\text { EW- } \\
\text { Direction } \\
\text { Shear } \\
\text { P2 (kip) }\end{array}$ & $\begin{array}{c}\text { NS- } \\
\text { Direction } \\
\text { Shear } \\
\text { P3 (kip) }\end{array}$ \\
\hline $\begin{array}{l}\text { Envelope of All } \\
\text { Soil Cases \& } \\
\text { Control Motions }\end{array}$ & $3.13 \mathrm{E} 4$ & $3.28 \mathrm{E} 4$ & $3.75 \mathrm{E} 4$ & $3.13 \mathrm{E} 4$ & $3.13 \mathrm{E} 4$ & $3.13 \mathrm{E} 4$ \\
\hline Case B4 & $2.58 \mathrm{E} 4$ & $2.90 \mathrm{E} 4$ & $2.98 \mathrm{E} 4$ & $3.13 \mathrm{E} 4$ & $3.12 \mathrm{E} 4$ & $3.09 \mathrm{E} 4$ \\
\hline Case B4S & $2.58 \mathrm{E} 4$ & $2.67 \mathrm{E} 4$ & $2.74 \mathrm{E} 4$ & $3.12 \mathrm{E} 4$ & $3.01 \mathrm{E} 4$ & $3.13 \mathrm{E} 4$ \\
\hline
\end{tabular}

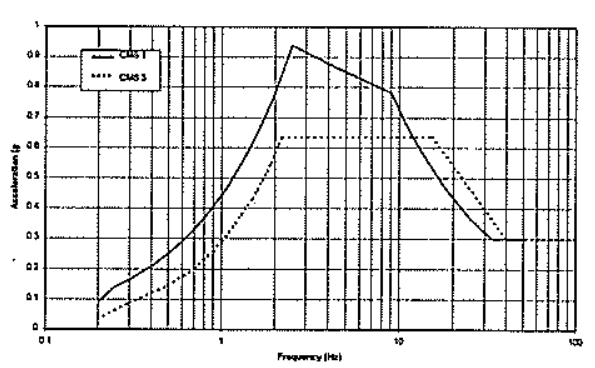

Figure 1 SSE Control Motions CMS1 and CMS3 for KNGR Standard Design

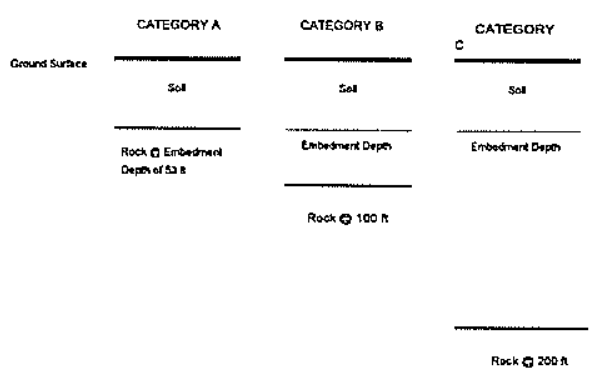

Figure 2 Generic Soil Site Category 


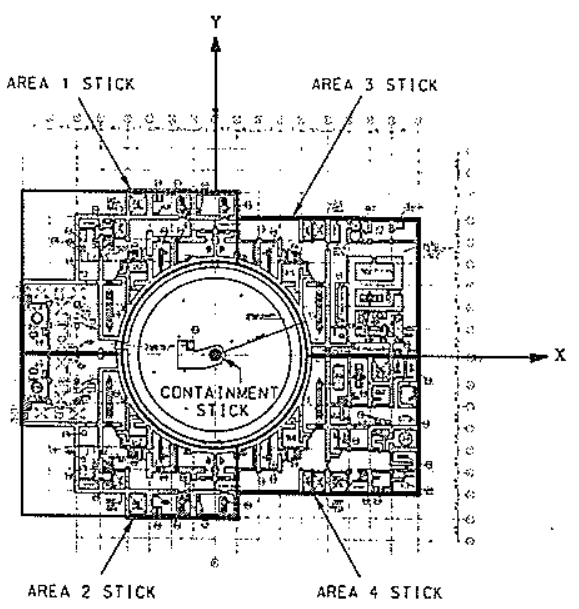

Figure 3 Plan Layout of NI

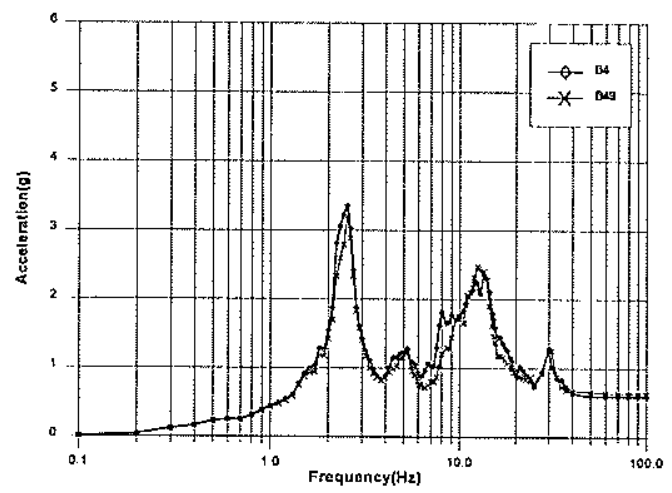

Figure 5 FRS at the roof of the Auxiliary Building

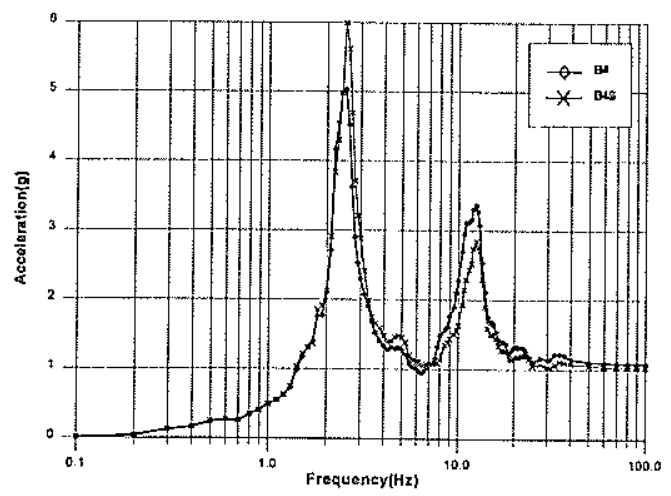

Figure $7 \mathrm{FRS}$ at the roof of the Inner Containment Dome

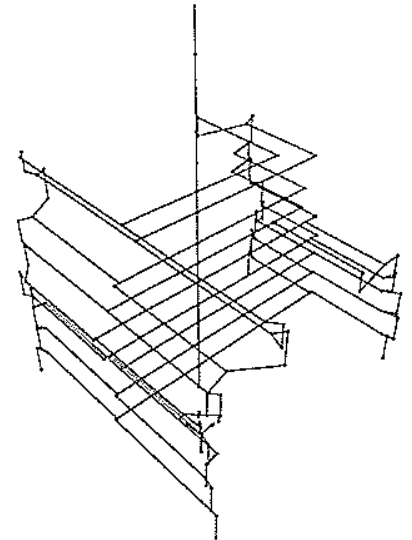

Figure '4 Stick Model of NI

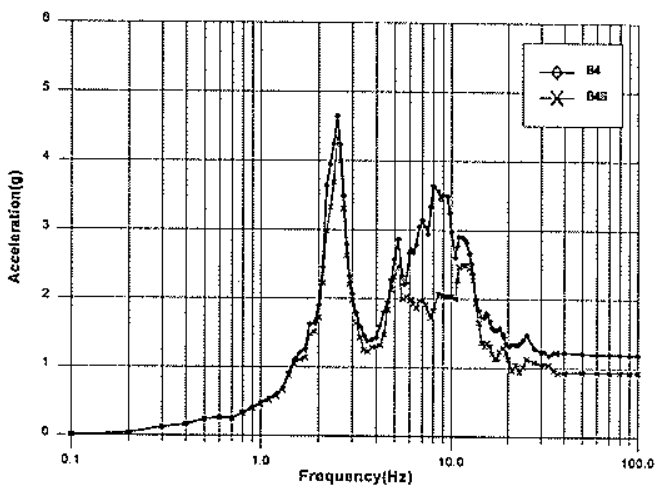

Figure 6 FRS at the top of the Outer Containment Dome

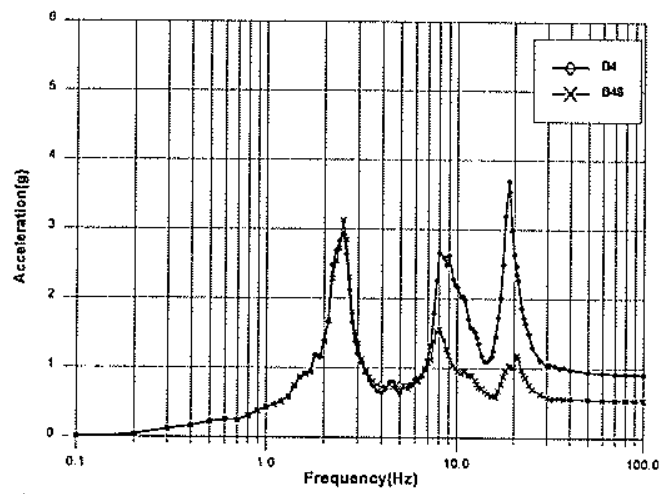

Figure 8 FRS at the top of the PrimarySecondary Shield 